\title{
Strategi Guru BK dalam Mengatasi Burnout Study Siswa SMKN 1 Widasari
}

\author{
Naelul Muna \\ Universitas Islam Negeri (UIN) Sunan Kalijaga \\ naelulmuna96@gmail.com
}

\begin{abstract}
The purpose of this study was determine the factors of students experiencing burnout study, describing the teachers strategy in overcoming the burnout study of students SMKN 1 Widasari, and knowing the obstacles of $\mathrm{BK}$ teachers in overcoming the burnout study of SMKN 1 Widasari students. The method used in this research is descriptive qualitative, a data collection tool with observation, interview and documentation. Best on the results of the study that the factors that influence students experience burnout study is because 1) family factors, there are some students experiencing broken home, 2) factors teachers who do not like subjects, and 3) subjects that are not liked. The strategies of BK teachers in overcoming student burnout studies are 1) conducted an assessment, 2) individual counseling, 3) learning motivation and games that stimulate students to be enthusiastic in learning, and 4) group counseling (Kopdar). The constraints felt by BK teachers in their strategies to overcome students burnout studies are the lack of cooperation between subjects teachers, homeroom teachers and school principals.
\end{abstract}

Keywords: SMK Widasari, teacher strategy, burnout study

\begin{abstract}
Abstrak
Tujuan penelitian ini untuk mengetahui faktor-faktor siswa mengalami burnout study, mendeskripsikan strategi guru dalam mengatasi burnout study siswa SMKN 1 Widasari,dan mengetahui hambatan-hambatan guru BK dalam mengatasi burnout study siswa SMKN 1 Widasari. Metode yang digunakan dalam penelitian ini yaitu kualitatif deskriptif, alat pengumpulan data dengan observasi, wawancara dan dokumentasi. Berdasarkan hasil penelitian bahwa faktor-faktor yang memengaruhi siswa mengalami burnout study yaitu karena 1) faktor keluarga, terdapat beberapa siswa mengalami broken
\end{abstract}


home, 2) faktor guru mata pelajaran yang tidak disukai, dan 3) mata pelajaran yang tidak disukai. Strategi guru BK dalam mengatasi burnout study siswa yaitu: 1) dilakukan assessment, 2) konseling individu, 3) motivasi belajar dan permainan-permainan yang menstimulasi siswa agar semangat dalam belajar, dan 4) konseling kelompok (Kopdar). Kendala yang dirasakan guru BK dalam strategi mengatasi burnout study siswa yaitu kurangnya kerjasama guru-guru matapelajaran, walikelas dan kepala sekolah.

Kata Kunci: SMK Widasari, strategi guru, burnout study

\section{Pendahuluan}

Belajar merupakan kewajiban bagi seluruh manusia, dari manusia itu dilahirkan ke muka bumi tak lepas dari proses belajar. Begitupun belajar dalam pendidikan formal, seperti dalam ruang lingkup lembaga sekolah, siswa dituntut untuk memenuhi standar kompetensi yang diselenggarakan oleh lembaga tersebut.Karena banyaknya tuntutan belajar siswa mengalami hambatanhambatan dalam proses belajar. Diantaranya yaitu burnout study atau kejenuhan dalam belajar. Burnout study adalahsuatu kondisi mental seseorang saat mengalami kejenuhan dalam belajar sehingga menyebabkan adanya rasa enggan, lesu, lelah yang amat sangat, dan tidak bersemangat dalam proses belajar. ${ }^{1}$

Burnout study dialami oleh individu dalam bersekolah (siswa) yang ditandai dengan adanya kelelahan emosional, depersonalisasi, dan perasaan rendah diri. ${ }^{2}$ Siswa yang mengalami burnout study menganggap dirinya sudah tidak mampu mengikuti pelajaran yang sedang diajar oleh gurunya di kelas dan melakukan aktivitas lain untuk menutupi rasa bosannya seperti mengobrol di kelas, tidur, bermain gadget, dan kegiatan lainnya yang menganggu proses belajar.

Adapun faktor-faktor yang menyebabkan siswa mengalami burnout study yaitu terbagi menjadi dua, ada faktor internal dan faktor eksternal; faktor internal siswa mengalami burnout study yaitu meliputi usia, jenis kelamin, kondisi fisik dan kondisi psikis siswa. Faktor eksternal siswa mengalami burnout study yaitu meliputi lingkungan sekolah yang kurang kondusif, metode mengajar yang dibawakan oleh guru, tugas-tugas yang diberikan bersifat monoton, dan kurangnya dukungan dari orang tua dan guru. ${ }^{3}$

${ }^{1}$ Thursan Hakim, Belajar Secara Efektif:Panduan Menemukan Teknik Belajar, Memilih Jurusan, Dan Menentukan Cita-Cita, Jakarta: Puspa Swara, 2000, hlm. 26.

${ }^{2}$ Fitri Ningsih, Efektivitas Teknik Relaksasi untuk Mengurangi Kejenuban Belajar. http://journal.student.uny.ac.id/,2016, hlm. 52. Diakses pada 3 Desember 2019.

${ }^{3}$ Rahmawati, Sholih, Bangun Yoga Wibowo, Pengembangan Media Paras (Paduan Audio Relaksasi Autogenin Sederhana) Sebagai Upaya Menurunkan Burnout Study. http://www.jurnal.untirta.ac.id/index.php/JPBK/article/view/3935, 2018, hlm. 176. Diakses pada 14 April 2020. 
Burnout study sebagai hambatan dalam proses belajar menjadi permasalahan siswa yang harus cepat ditangani oleh pihak sekolah, terutama guru Bimbingan Konseling (BK), upaya-upaya preventif dan penanganan harus terus dilakukan dalam sekolah. Peneliti terdahulu telah melakukan penelitian berupa pemberian intervensi kepada siswa yang mengalami burnout study. Diantaranya penerapan kombinasi teknik relaksasi dan selfintruction, ${ }^{4}$ penelitian ini dilakukan oleh Zuni Eka Khusumawati dengan metode penelitian kuantitatif one grouppretest-posttest design, hasil penelitiannya menunjukkan bahwa penerapan kombinasi teknik relaksasi dan self-intruction dapat mengurangi kejenuhan belajar siswa kelas XI IPA 2 SMA Negeri 22 Surabaya. Penelitian selanjutnya dilakukan oleh Naeila Rifatil Muna dengan menggunakan Teknik self-regulation learning, ${ }^{5}$ metode penelitian yang digunakan adalah metode kuantitatif dengan one group pretest-posttest design, hasil penelitian ini menunjukkan teknik self-regulation learning efektif untuk mengurangi tingkat kejenuhan belajar siswa di SMA Insan Cendekia Sekarkemuning Cirebon. Penelitian lain menunjukkanteknik musik klasik (Mozart)efektif untuk menurunkan kejenuhan belajar siswa kelas XI SMAN 4 Yogyakarta, ${ }^{6}$ penelitian ini dilakukan oleh Novian Gangga Kurniawan dengan menggunakan metode kuantitatif Eksperimennonequivalent control group design.Banyak peneliti terdahulu yang meneliti berbagai teknik untuk mengatasi kejenuhan belajar siswa, tetapi belum ada penelitian yang fokus meneliti bagaimana strategi guru BK dalam mengatasi kejenuhan belajar siswa di sekolah. Hal ini penting untuk diteliti, karena para guru BK mempunyai strategi dan penanganannya masing-masing dalam mengatasi permasalahan siswa di sekolah terutama kejenuhan belajar siswa atau burnout studysiswa.Dari telaah beberapa penelitian terdahulu yang peneliti lakukanmenjadi peluang bagi peneliti dan sebagai pembaharuan dalam kajian ilmiahuntuk melakukan penelitian mengenai strategi guru BK dalam mengatasi burnout study siswa di sekolah.

Demikian juga sekolah yang dijadikan tempat penelitian yakni di SMKN 1 Widasari, berdasarkan pada studi pendahuluan yang dilakukan pada observasi awal tanggal 20 November 2019 dengan guru BK bapak Alvy Mardiana, S.Pd. dan sejumlah siswa kelas XI dan XII, ditemukan bahwa banyak siswa yang mengalami burnout study. Terutama pada siswa kelas XI dan XII karena

${ }^{4}$ Zuni Eka Khusumawati, Penerapan Kombinasi Teknik Relaksasi dan Self-Intructionuntuk Mengurangi Kejeuban Belajar Siswa Kelas XI IPA 2 SMA Negeri 22 Surabaya, https://jurnalmahasiswa.unesa.ac.id/index.php/jurnal-bk-unesa/article/view/9933, 2015. Diakses pada 29 April 2020.

${ }^{5}$ NaeilaRifatil Muna, Efektifitas Teknik Self Regulation Learning dalam Mereduksi Tingkat Kejenuban Belajar Siswa di SMA Insan Cendekia Sekarkemuning Cirebon,http://www.syekhnurjati.ac.id/jurnal/index.php/holistik/article/view/450, 2016. Diakses pada 29 April 2020.

${ }^{6}$ NovianGangga Kurniawan, Efektifitas Musik. Klasik. (Mozart) Untuk. Menurunkan Kejenuban

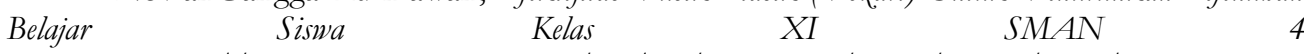
Yogyakarta,http://journal.student.uny.ac.id/ojs/ojs/index.php/fipbk/article/view/4036, 2016. Diases pada 29 April 2020. 
banyaknya kegiatan di sekolah termasuk kegiatan organisasi intra sekolah dan tugas-tugas sekolah lainnya. Adapun akibat dari kejenuhan belajar siswa ini adalah siswa sering membolos, tidak memperhatikan penjelasan guru di kelas, tidak mau menulis, dan tidak mau mengikuti mata pelajaran. Dari kejenuhan belajar ini juga berakibat pada prestasi belajar siswa menurun, dan terjadi kesenggangan antara murid yang mengalami burnout study dengan guru mata pelajaran.

Peran guru BK memberikan layanan bimbingan konseling di sekolah untuk membantu siswa dapat menyelesaikan permasalahan-permasalahan yang dihadapi agar siswa menjadi pribadi yang mandiri. Peranan ini sangat diperlukan di sekolah sehingga kegiatan belajar mengajar dapat berlangsung baik sesuai yang diharapkan. ${ }^{7}$ Dalam hal ini guru BK harus memiliki teknik dan strategi untuk mengatasi masalah belajar siswa yaitu burnout study. Oleh karena itu peneliti tertarik untuk meneliti bagaimana strategi guru BK dalam mengatasi burnout study siswa di SMKN 1 Widasari, yang mana burnout study ini sudah menjadi masalah yang kompleks untuk segera ditangani dan diberikan perlakuan.

Pada penelitian ini, guru BK yang diteliti adalah tenaga yang merangkap atau teacher-counselor, yaitu guru BK yang merangkap sebagai guru mata pelajaran dan menjadi wali kelas. Jadi tenaga ini adalah part-time counselor dan part-time teacher, dengan perbandingan waktu $50 \%-50 \% .^{8}$

Dalam kurun 2 tahun terakhir guru BK SMKN 1 Widasari telah mengupayakan layanan-layanan untuk menanggulangi permasalahan siswa, terutama mengenai masalah burnout study. Akan tetapi masalah tersebut tidak langsung selesai begitu saja, faktor-faktor siswa mengalami burnout study pun sangat berperan penting dalam proses guru melakukan assessment untuk ditindak lanjuti kepada tahap konseling. Faktor internal siswa yaitu berupa motivasi dan keinginan untuk berubah ke arah yang lebih baik pun sebagai penentu keberlangsungan proses konseling. Banyak kasus yang terjadi yaitu seperti siswa dikonseling pada hari ini, masalah selesai hanya di sekolah saja. Akan tetapi pada keesokan harinya siswa kembali membawa beban masalahnya dari rumah sehingga masalah itu terus terulang setiap harinya.

Dari apa yang sudah dijelaskan mengenai permasalahan dan ketertarikan peneliti untuk meneliti masalah tersebut maka rumusan masalah pada penelitian ini adalah: 1) apa faktor-faktor siswa mengalami burnout study?, 2) bagaimanakah strategi guru BK dalam mengatasi burnout study siswa SMKN 1 Widasari?, 3) apa yangmenjadi hambatan guru BK dalam mengatasi burnout study siswa SMKN 1 Widasari?.

\footnotetext{
${ }^{7}$ Abdul Rahman, Peranan Guru Bimbingan dan Konseling Terbadap Pelaksanaan Bimbingan Belajar di Smk Negeri 1 Loksado, https://ojs.uniska-bjm.ac.id/index.php/ANNUR/article/view/580, 2015, hlm. 3. Diakses pada 3 Desember 2019.

${ }^{8}$ W.S. Winkel, Bimbingan dan Konseling di Sekolah Menengah.Jakarta: PT Grasindo, 1991.
} 
Tujuan penelitian ini yaitu: 1) untuk mengetahui faktor-faktor siswa mengalami burnout study, 2) untuk mendeskripsikan strategi guru dalam mengatasi burnout study siswa SMKN 1 Widasari, 3) untuk mengetahui hambatan-hambatan guru BK dalam mengatasi burnout study siswa SMKN 1 Widasari.

Penelitian ini merupakan penelitian deskriptif menggunakan pendekatan kualitatif. Penelitian kualitatif merupakan metode-metode untuk mengeksplorasi dan memahami makna yang berasal dari masalah sosial dan kemanusiaan. Dalam hal ini, peneliti berusaha membangun makna tentang suatu fenomena berdasarkan pandangan-pandangan dari para partisipan dengan cara mengobservasi perilaku para partisipan dan terlibat langsung dalam aktivitasaktivitas mereka. ${ }^{10}$

Penelitian ini dilakukan di SMKN 1 Widasari, pemilihan lokasi ini atas beberapa pertimbangan yaitu karena di sekolah ini banyak siswa mengalami kejenuhan belajar atau burnout study. Subjek dalam penelitian ini adalah guru bimbingan konseling (BK) dan siswa kelas XI dan XII SMKN 1 Widasari yang mengalami burnout study.

Teknik yang digunakan untuk mengumpulkan data yaitu dengan observasi, wawancara, dan dokumentasi. Teknik observasi adalah teknik pengumpulan data dengan cara mengamati tidak terbatas pada orang, tetapi juga pada objek-objek alam seperti kondisi lingkungan tempat penelitian, ${ }^{11}$ dalam hal ini peneliti mengamati fenomena dan keadaan sekitar SMKN 1 Widasari.Observasi dilakukan dengan cara mengamati proses kegiatan pembelajaran didalam kelas maupun diluar kelas dan proses layanan bimbingan konseling yang dilakukan oleh guru BK.Metode wawancara yang dilakukan adalah wawancara mendalam untuk memperoleh informasi lebih dalam terkait dengan penelitian untuk mengetahui strategi guru BK dalam mengatasi burnout study siswa. Wawancara dilakukan pada guru BK di SMKN 1 Widasari. Dan dengan dokumentasi untuk mengetahui strategi guru BK dalam mengatasi burnout study.

Tujuan penelitian dengan menggunakan metode ini adalah ingin mengetahui bagaimana strategi Guru BK dalam mengatasiburnout study siswa di SMKN 1 Widasari dengan cara mengumpulkan data selengkap-lengkapnya, kemudian data yang telah diperoleh akan dideskripsikan dan selanjutnya diinterpretasikan. Tempat penelitian ini dilaksanakan di SMKN 1 Widasari yang beralamat di Jl. Ujungaris, Ujungpendokjaya, Widasari, Kabupaten Indramayu.

'John W. Kreswell, Research Design Pendekatan Metode Kualitatif, Kuantitatif, dan Campuran, 2018, Yogyakarta: Pustaka Pelajar, hlm. 4.

${ }^{10}$ Ibid., hlm. 24.

${ }^{11}$ Sugiyono, Metode Penelitian Kuantitatif, 2019, Bandung: Alfabeta, hlm. 223. 


\section{Hasil dan Pembahasan}

Dari hasil observasi dan wawancara pada bulan November 2019 dengan guru BK bahwa banyak siswa yang mengalami kejenuhan belajar atau burnout study, dapat dilihat dari kurang aktifnya siswa di kelas, tidak memperhatikan guru ketika proses belajar mengajar berlangsung, tidak mau mengerjakan tugas yang diberikan guru, nilai rapot yang menurun, dan membolos.

"banyak murid di sini yang mengalami kejenuban dalam belajar, terutama yang kelas XI sama kelas XII, kalau kelas X itu masih pada semangat, antusias belajarnya masib ada gitu. Ya saya dapat laporan dari guru-guru kalau kelas ini siswa-siswanya suka pada ngobrol sendiri,nyanyi-nyanyi, tidur, pada sibuk sendiri pokoknya anak-anak itu kalau gurunya lagi ngajar. Kalau dikasih tugas pada ngeluh, ya dari prestasi belajarnya kan jadi menurun, babkan ada saja yang sampai membolos "12 Widasari:

Hal serupa juga dikatakan oleh ibu Najiah selaku guru BK di SMKN 1

"karena kita juga ada jamnya masuk ke kelas-kelas, jadi kita melihat langsung bagaimana suasana belajar di kelas, murid-murid yang dilaporkan sama guru mata pelajaran kepada guru BK bahwa murid-murid ini mengalami permasalahan dalam proses belajarmya"13

Adapun faktor-faktor yang memengaruhi burnout study siswa menurut guru BK di SMKN 1 Widasari yaitu terdapat faktor internal dan faktor eksternal. Faktor internal siswa mengalami burnout study yaitu karena kurangnya minat belajar siswa dan motivasi diri siswa untuk belajar berkurang. Faktor eksternal yang menyebabkan siswa mengalami burnout study yaitu: 1) Faktor keluarga, terdapat beberapa siswa mengalami broken home, permasalahan keluarga terutama orang tua siswa yang tengah mengalami konflik berakibat pada menurunnya motivasi belajar siswa dan siswa menjadi sangat emosional di sekolah. 2) Faktor guru mata pelajaran yang tidak disukai, ketika mata pelajaran yang diajarkan oleh guru tertentu dan siswa merasa tidak nyaman maka siswa sering melakukan pemberontakan di kelas, seperti tidak mau menulis, tidak mau mendengarkan penjelasan pelajaran dari guru, tidur di kelas dan sampai membolos. 3) Mata pelajaran yang tidak disukai juga mengakibatkan siswa mengalami burnout study, siswa menjadi sering melamun di kelas, mengobrol dengan teman, bernyanyi di kelas, mengantuk, dan asyik dengan kesibukannya sendiri dan tidak memperhatikan pelajaran yang sedang berlangsung.

"ketika kita guru BK melakukan assessment kepada murid-murid yang bermasalah, rata-rata faktor yang memengarubi mereka mengalami kejenuban dalam belajar karena faktor keluarga. Ada beberapa murid mengalami broken

\footnotetext{
${ }^{12}$ wawancara dengan bapak Alvy Mardiana selaku guru BK, 20 November 2019.

${ }^{13}$ Wawancara dengan ibu Najiah selaku guru BK, 20 November 2019.
} 
home, lalu ada yang mereka gak suka sama gurunya, ada juga yang gak suka sama pelajarannya ${ }^{\text {,14 }}$

Dari data yang sudah didapat dari guru BK, peneliti juga melakukan wawancara dengan sejumlah siswa yang mengalami burnout study pada tanggal 26 November 2019. UA menjelaslan "kadang jenuh sekolah pengennya kabur aja kemana gitu. Di rumah pusing liat orang tua gak akur, di sekolah juga pusing belajar" ${ }^{p 15}$ Berbeda dengan $\mathrm{W}, \mathrm{W}$ mengatakan :

"saya gak tinggal sama orang tua, karena mereka udah cerai dan udah punya keluarga masing-masing. Bapak udah nikah lagi, ibu juga udah nikah lagi, jadi mereka bingung kayaknya ga ada yang mau bawa saya, gak ada yang peduli juga. Jadi ya saya tinggal sama nenek. kakek sama uwa. Kalo di sekolah ya asal masuk aja, kasian juga sama nenek, kakek yang udah ngurusin masa si saya gak sekolab"16 home.

Hasil wawancara di atas dengan dua siswa yang mengalami broken

"kalau saya sib karena gak suka sama guru biasanya mba, jadi males juga ngikutin pelajarannya, terlalu kaku gak ada bercandanya dikit kek. Ya nakal-nakalnya saya bolos kalau pas pelajarannya dia. Kalau masuk ya asal masuk aja, bosen dengerinnya. Kalau ngasib tugas disuruh nulis terus "17

Hasil wawancara di atas dengan siswa yang mengalami kejenuhan belajar karena tidak menyukai salah satu guru mata pelajaran. R mengatakan "gak suka sama pelajaran matematika, pusing itung-itungannya" 18 Sementara menurut $\mathrm{K}$, "saya gak suka sama pelajaran bahasa Inggris, gak ngerti ngomong apa. Kadang guruunya juga gak jelas neranginnya, kebanyakan ngasih tugasnya aja"19

Dari hasil wawancara peneliti dengan lima siswa yang mengalami burnout study mengenai faktor-faktor yang memengaruhi siswa tersebut mengalami burnout study yaitu mayoritas siswa menjawab karena beban belajar yang menyebabkan mereka jenuh belajar, mereka tidak menyukai mata pelajaran yang menuntut mereka untuk banyak menulis, dan karena guru mata pelajaran yang tidak disukai, guru yang terlalu kaku dalam menyampaikan pelajaran sehingga siswa menjadi jenuh dan bosan. Mereka mengatakan ketika terdapat jadwal mata pelajaran yang diajarkan oleh guru tertentu yang mereka anggap guru tersebut terlalu kaku dalam menyampaikan pelajaran, mereka lebih memilih untuk membolos. Terdapat dua siswa yang mengalami burnout study karena faktor keluarga (broken home), orang tua siswa yang tengah mengalami konflik rumah

\footnotetext{
${ }^{14}$ Wawancara dengan bapak Alvy Mardiana, 20 November 2019.

${ }^{15}$ Wawancara dengan UA, 26 November 2019.

${ }^{16}$ Wawancara dengan W, 26 November 2019.

${ }^{17}$ Wawancara dengan T, 26 November 2019.

${ }^{18}$ Wawancara dengan R, 26 November 2019.

${ }^{19}$ Wawancara dengan K, 26 November 2019.
} 
tangga sehingga siswa mengalami kelelahan emosional dan ketika berangkat ke sekokah mereka tidak dapat menerima beban-beban pelajaran yang ada.

Strategi guru BK terhadap burnout study siswa yaitu dengan diadakannya layanan-layanan bimbingan konseling di sekolah. Layanan yang digunakan guru BK SMKN 1 Widasari sebagai strategi mengatasiburnout study siswa yaitu dengan langkah awal dilakukannya assessment, assessment yaitu menilai atau mengenali siswa secara mendalam dari berbagai aspek, ${ }^{20}$ hal ini penting dilakukan agar guru BK dapat menggali informasi lebih dari siswa yang bermasalah untuk dilakukan proses tindakan konseling yang akan dilakukan untuk membantu siswa mengatasi permasalahannya.

Setelah dilakukannya assessment dilanjutkan dengan layanan konseling perorangan atau konseling individu, yaitu layanan bimbingan dan konseling individu yang memungkinkan siswa mendapat layanan secara langsung secara perorangan (tatap muka) dengan guru BK untuk membantu siswa secara individu dapat mengatasi permasalahan yang dialami. ${ }^{21}$ Alvy Mardiana mengatakan "kita selaku guru BK selalu mengupayakan strategi-strategi untuk mengatasi permasalahan siswa, paling sering kita memberikan layanan konseling individu, untuk memberikan konseling langsung ke siswa secara perorangan",22

Adapun mata pelajaran Budi Pekerti (BP) yang diampu oleh guru BK, peran guru BK ketika mengajar yaitu memberikan motivasi dan permainanpermainan yang menstimulasi siswa agar tidak jenuh di kelas. Siswa meminta guru BK untuk tidak memberikan tugas seperti menulis ataupun penjelasan teori-teori yang terlalu banyak dikarenakan sudah jenuh dengan pelajaranpelajaran lain. Guru BK SMKN 1 Widasari pun berharap dengan hadirnya guru BK di kelas dapat me-refresh semangat belajar siswa.Ibu Najiah mengatakan "guru BK ada jamnya masuk ke kelas-kelas itu pas pelajaran BP (Budi Pekerti), anak-anak pada gak mau dikasih tugas lagi katanya udah bosen. Jadi kita seringnya ngasih game-game atau motivasi biar mereka semangat lagi",23

Dari hasil wawancara di atas strategi guru BK dalam mengatasi burnout study dengan memberikan motivasi dan game atau permainan untuk kembali merefresh atau menyegarkan kembali semangat belajar siswa dalam belajar. Teknik permainan yang diberikan guru BK di ruang kelas terbukti efektif membuat kelas lebih hidup dan siswa kembali semangat.

Dalam strategi mengatasi burnout study ini guru BK SMKN 1 Widasari tidak hanya memberikan layanan bimbingan dan konseling di sekolah saja,

\footnotetext{
${ }^{20}$ Siti Wahyuni Siregar,Assessment dalam Bimbingan dan Konseling,http://194.31.53.129/index.php/Hik/article/viewFile/696/611, 2016, hlm. 2. Diakses pada 4 Desember 2019.

${ }^{21}$ Samsul Munir Amin, Bimbingan dan Konseling Islam, Jakarta: Amzah, 2015, hlm. 289.

${ }^{22}$ Wawancara dengan bapak Alvy Mardiana, 2 Desember 2019.

${ }^{23}$ Wawancara dengan ibu Najiah, 2 Desember 2019.
} 
melainkan di luar sekolah juga guru BK melakukan konseling kelompok yang mereka sebut dengan Kopdar (Kopi Darat), ${ }^{24}$ dalam hal ini sebutan kopdar disepakati oleh siswa dan guru BK SMKN 1 Widasari. Layanan konseling kelompok, yaitu layanan bimbingan dan konseling yang memungkinkan peserta didik memperoleh kesempatan untuk membahas dan mengatasi permasalahan yang dialaminya melalui dinamika kelompok. Adapun masalah yang dibahas adalah masalah pribadi yang dialami masing-masing angggota kelompok. ${ }^{25}$

"bisa disebut konseling kelompok juga, tapi kita biasa bilangnya itu kopdar (kopi darat), biasanya itu saya sama murid laki-laki, karena mayoritas di sini muridnya laki-laki ya, itu setiap hari sabtu. Sering itu saya ajak anak-anak yang sudah bermasalah. Sambil ngobrol-ngobrol santai saya selipin pertanyaanpertanyaan buat menggali lebih informasi apa si yang tengah mereka rasakan dan alami dan apa yang bisa saya bantu,26

Dalam konseling kelompok yang dilakukan di luar sekolah ini atau yang guru BK SMK 1 Widasari dan para siswanya sebut dengan Kopdar. Dilakukan dalam rangka strategi guru BK dapat menggali lebih informasi permasalahan siswa yang tidak didapatkan ketika konseling individu di sekolah, guru BK mengatakan dengan diadakannya Kopdarini siswa lebih terbuka dan santai serta nyaman dalam membahas permasalahan-permasalahan yang tengah dialami. Dan guru BK dapat dengan mudah memberikan saran dan motivasi yang mudah diterima sesuai dengan kebutuhan para siswanya.

Dari pengakuan para siswa yang sudah mengikuti kegiatan Kopdar tersebut, dikatakan bahwa berbeda ketika kegiatan bimbingan dan konseling tersebut diadakan di sekolah dan di luar sekolah, diantaranya yaitu ketika di sekolah mereka masih mengenakan seragam dan berhadapan dengan guru BK yang mengenakan seragam dinasnya terasa seperti ada sekat atau batasan yang membuat para siswa tidak bisa leluasa dalam menceritakan permasalahpermasalah belajar yang sedang dihadapi, berbeda dengan ketika kegiatan Kopdar, para siswa lebih nyaman dalam suasana santai dan menikmati kopi bersama guru BK yang terasa seperti teman mereka. Salah seorang siswa mengatakan "iya pak Alvy sering ngajak kopdar, lebih enak ngobrolnya di sana sambil ngopi. Ya kita juga sambil curhat-curhat. Pak Alvy enak diajak ngobrol kalau di luar. Kalau di sekolah tuh beda aja auranya, kerasa banget gurunya apalagi liat pake seragamnya itu. Kalau di luar sekolah enak kaya temen sendiri gitu gak ada sekatnya"27

Adapun kendala yang dirasakan guru BK dalam strategi mengatasiburnout study siswa yaitu kurangnya kerjasama guru-guru mata pelajaran, wali kelas dan

\footnotetext{
${ }^{24}$ kopdar adalah sebuah istilah yang mengarah kepada ajang pertemuan antar sesama pengguna yang umumnya sudah saling kenal lewat radio, Internet, sosial media atau grup chatting. (https://id.wikipedia.org/wiki/Kopi_darat), diakses pada 29 April 2020.

${ }^{25}$ Op. Cit., hlm. 292.

26Wawancara dengan bapak Alvy Mardiana, 2 Desember 2019.

${ }^{27}$ Wawancara dengan murid (T), 2 Desember 2019.
} 
kepala sekolah. Sehingga guru BK merasa kurang efektif dalam mengatasi permasalahan yang ada di sekolah terutama masalah burnout study, kendala yang lain yaitu kurangnya tenaga guru BK, di SMKN 1 Widasari untuk sekarang hanya ada 2 (dua) guru BK yaitu 1 guru BK laki-laki dan 1 guru BK perempuan, dalam menjalankan tugas memberikan layanan bimbingan konseling kepada seluruh siswa masih belum terjangkau secara keseluruhan, yang dikarenakan guru BK merangkap sebagai guru mata pelajaran dan menjadi wali kelas juga.

"pasti ada kendalanya, terutama kita kekurangan tenaga untuk menangani semua murid. kurang kerjasamanya juga sama guru-guru yang lain seolah-olah semua permasalahan siswa itu harus guru BK yang nanganin, dalam hal ini juga kurang apresiasi juga dari kepala sekolah. Apalagi kita juga di sini bukan cuma jadi guru BK juga tapi merangkap tugas yang lainnya,28

Dalam hal ini strategi guru BK dalam menanganiburnout study siswa yaitu dengan diadakannya konseling individu yang dilakukan setiap hari senin sampai jumat di sekokah ketika ada rujukan dari wali kelas untuk menangani kasus siswa yang mengalami burnout study. Dan kegiatan Kopdaryang dilakukan seminggu satu kali setiap hari sabtu dengan megajak siswa-siswa yang bermasalah terutama yang mengalami burnout study. Upaya-upaya tersebut terus dilakukan guru BK untuk mengurangi permasalah yang tengah dihadapi siswa yang sampai menganggu proses belajar mereka di sekolah.

Adapun perubahan yang dirasakan guru BK setelah memberikan layanan bimbingan dan konseling yaitu terdapat perubahan pada siswa yang dibimbimbingnya, seperti ada harapan baru bagi siswa untuk pergi belajar ke sekolah karena mereka merasa nyaman ada guru BK yang bisa membantu siswa kapanpun ketika sedang dibutuhkan dan mengadukan permasalahanpermasalahan yang tengah dalami. Adapun perubahan perilaku burnout study siswa menjadi bisa lebih konsentrasi di kelas, dapat mengikuti mata pelajaran dengan baik, mulai mau menulis tugas dan tidak membangkang dengan guru. Ibu Alvy Mardiana mengatakan :

"terasa perubahannya setelah diberikan layanan konseling, karena mereka juga sudah percaya dengan kita guru BK. Jadi apapun yang kita berikan sebagai saran dan motivasi itu bisa dijalankan. Harapannya siswa terus menjadi lebih baik seperti yang kita barapkan, ${ }^{\text {,29 }}$

Dari hasil observasi, wawancara dan dokumentasiyang peneliti lakukan untuk mengetahui strategi guru BK dalam menangani burnout study di SMKN 1 Widasaritelah didapat jawaban atas rumusan masalah. Strategi yang digunakan guru BK SMKN 1 Widasari dalam mengatasi burnout study siswa yaitu dengan melakukan assessment terlebih dahulu. Dalam hal ini guru BK menggali informasi siswa yang bermasalah untuk mengetahui akar permasalahan sehingga

${ }^{28}$ Wawancara dengan ibu Najiah, 11 Desember 2019.

${ }^{29}$ Wawancara dengan Ibu Alvy Mardiana, 11 Desember 2019. 
bisa ditindak lanjuti ke tahap pemberian bantuan berupa bimbingan dan koseling. Setelah diberikan assessment guru BK memberikan layanan konseling individu. Guru BK bertatap muka langsung dengan siswa secara individuuntuk membahas permasalahan yang tengah dialami siswa dan guru BK memfasilitasi siswa agar siswa dapat menyelesaikan masalahnya sendiri.

Adapun strategi teknik bermain yang dilakukan oleh guru BK SMKN 1 Widasari kepada siswa di kelas secara berkelompok. Hal ini sama dengan teori Play Therapy yaitu salah satu konseling kelompok yang pada dasarnya merupakan jenis terapi yang mengikuti kesenangan konseli (peserta didik) dimana pada usia ini kegiatan yang menurut mereka (peserta didik) menyenangkan adalam bermain. Dalam play therapy ini kesenangan menjadi dasar bagi pemulihan kondisi emosi mereka. ${ }^{30}$

Konseling kelompok terdiri dari 4-8 konseli yang bertemu dengan 1-2 konselor (Pauline Harrison, 2002), dalam prosesnya konseling kelompok dapat membicarakan beberapa permasalahan yang dialami konseli, membantu individu dalam situasi kelompok, agar individu dapat mengembangkan kemampuan interaksi dan meningkatkan komunikasi, mengembangkan harga diri, dan keterampilan-keterampilan dalam mengatasi masalah. ${ }^{31}$

\section{Penutup}

Berdasarkan hasil penelitian dan pembahasan yang telah diuraikan di atas, maka diperoleh kesimpulan bahwaFaktor-faktor yang memengaruhi siswa mengalami burnout study yaitu karena 1) Faktor keluarga, terdapat beberapa siswa mengalami broken home, 2) Faktor guru mata pelajaran yang tidak disukai, dan 3) Mata pelajaran yang tidak disukai.

Strategi guru BK dalam mengatasiburnout study siswa yaitu: 1) dilakukan assessment, 2) konseling individu, 3) motivasi belajara dan permainanpermainan yang menstimulasi siswa agar semangat dalam belajar, 4) konseling kelompok (Kopdar).

Kendala yang ditemukan oleh guru BK yaitu kurangnya kerjasama guruguru mata pelajaran, wali kelas dan kepala sekolah. Sehingga guru BK merasa kurang efektif dalam mengatasi permasalahan burnout study siswa. Kendala yang lain yaitu kurangnya tenaga guru BK, di SMKN 1 Widasari untuk sekarang hanyaada 2 (dua) guru BK yaitu 1 guru BK laki-laki dan 1 guru BK perempuan, dalam menjalankan tugas memberikan layanan bimbingan konseling kepada seluruh siswa masih belum terjangkau secara keseluruhan, yang dikarenakan guru BK merangkap sebagai guru mata pelajaran dan menjadi wali kelas juga.

\footnotetext{
${ }^{30}$ Dede Rahmat Hidayat, Konseling di Sekolah Pendekatan-Pendekatan Kontemporer, Jakarta: Prenadamedia Group, 2018, hlm. 27-28.

${ }^{31}$ Edi Kurnanto, Konseling Kelompok, Bandung: Alfabeta, 2014, hlm. 7.
} 


\section{Bibliografi}

Abdul Rahman. Peranan Guru Bimbingan Dan Konseling Terbadap Pelaksanaan Bimbingan Belajar di SMK Negeri 1 Loksado. An-Nur: Jumal Mabasiswa Bimbingan dan Konseling, 1(3), 1-14. Doi: http://dx.doi.org/10.31602/jmbkan.v1i3.580.

Fitri Ningsih. 2016. Efektivitas Teknik Relaksasi untuk. Mengurangi Kejenuhan Belajar. Jurnal Riset Mabasiswa Bimbingan dan Konseling, 5(7), Doi:http://journal.student.uny.ac.id/.

Hakim, Thursan. Belajar Secara Efektif:Panduan Menemukan Teknik Belajar, Memilih Jurusan, dan Menentukan Cita-Cita. Jakarta: Puspa Swara. 2000.

John W. Kreswell.Research Design Pendekatan Metode Kualitatif, Kuantitatif, dan Campuran. Yogyakarta: Pustaka Pelajar. 2018.

Kurnanto, M. Edi.Konseling Kelompok. Bandung: Alfabeta. 2014.

Munir Amin, Samsul. Bimbingan dan Konseling Islam. Jakarta: Amzah. 2015.

Naeila Rifatil Muna.Efektifitas Teknik Self Regulation Learning dalam Mereduksi Tingkat Kejenuban Belajar Siswa di SMA Insan Cendekia Sekarkemuning Cirebon.Holistik: journal for Islamic Social Sciences,14(2), 57-78.Doi: http://www.syekhnurjati.ac.id/jurnal/index.php/holistik/article/view/450/395.

Novian Gangga Kurniwan. Efektifitas Musik Klasik (Mozart) Untuk. Menurunkan Kejenuhan Belajar Siswa Kelas XI SMAN 4 Yogyakarta. Jurnal Riset Mahasiswa Bimbingan dan Konseling, $\quad 5(7)$. Doi:http://journal.student.uny.ac.id/ojs/ojs/index.php/fipbk/article/view/403 $\underline{6 / 3691}$.

Rahmawati, Sholih, Bangun Yoga Wibowo. Pengembangan Media Paras (Paduan Audio Relaksasi Autogenin Sederbana) Sebagai Upaya Menurunkan Burnout Study. Jurnal Riset Mahasiswa Bimbingan dan Konseling, 3(2), 174-190. Doi: http://www.jurnal.untirta.ac.id/index.php/JPBK/article/view/3935/2824.

Siti Wahyuni Siregar. 2016. Assessment dalam Bimbingan dan Konseling. Hikmah, 1-18. Doi:http://194.31.53.129/index.php/Hik/article/viewFile/696/611.

Sugiyono. Metode Penelitian Pendidikan. Bandung: Afabeta. 2013.

Wawancara dengan guru BK dan murid SMKN 1 Widasari. 2019.

W.S. Winkel. Bimbingan dan Konseling di Sekolah Menengah. Jakarta: PT Grasindo. 1991.

Zuni Eka Khusumawati. Penerapan Kombinasi Teknik Relaksasi dan Self-Intruction untuke Mengurangi Kejeuban Belajar Siswa Kelas XI IPA 2 SMA Negeri 22 Surabaya. Jurnal BK UNESA, 5(1), 1 10.Doi:https://jurnalmahasiswa.unesa.ac.id/index.php/jurnal-bk unesa/article/view/9933/9727. 